\title{
The assessment of maternal deaths between 2015 and 2020 in Elazığ, Turkey
}

\author{
İbrahim Batmaz (D), Salih Burçin Kavak ${ }^{1}$ (D) Ebru Çelik Kavak' (iD), Evrim Gül² \\ Cengiz Şanlı $^{3}$ (D) , Gülay Bulu ${ }^{4}$ (ID), Hasan Burak Keser ${ }^{1}$ \\ ${ }^{1}$ Department of Obstetrics and Gynecology, Faculty of Medicine, Firat University, Elazı $\breve{g}$, Turkey \\ ${ }^{2}$ Department of Emergency Medicine, Faculty of Medicine, Firat University, Elazı̆̆, Turkey

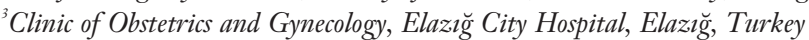 \\ ${ }^{4}$ Clinic of Obstetrics and Gynecology, Kovancılar State Hospital, Elaziğ, Turkey
}

\begin{abstract}
Objective: To determine the maternal deaths and the factors affecting them in our city.

Methods: The maternal deaths occurred in our city between January 2015 and June 2020 were reviewed retrospectively. The review was conducted by checking "Maternal Death Registry Forms" of the Provincial Directorate of Health. In cases where additional data related with the cause of death were required, the relatives of the cases, associated family practitioner, The Council of Forensic Medicine or local authorities were contacted. The data of the cases including age, gravida, parity, abortion, delivery type, week of gestation during delivery, period of death and maternal deaths due to direct, indirect and incidental causes were recorded. Based on total live births and maternal deaths within 6.5 years, maternal mortality rate was found as the maternal death number per 100,000 live births. Descriptive statistics were used for the statistical analysis of the data.

Results: A total of 46.618 live births occurred between 2015 and 2020 in Elazı̆g. The number of maternal deaths due to direct and indirect causes is 7 , and maternal mortality rate was found $15.01 / 100,000$. Hypertensive diseases during pregnancy $(n=3,42.8 \%)$, pulmonary embolism $(n=1,14.3 \%)$ and cerebral thrombosis $(n=1,14.3 \%)$ were among the natural causes of maternal deaths. Indirect cause for maternal death was cardiac diseases $(n=2,28.6 \%)$. When they were categorized according to the Three Delays Model, there were 3 death cases in the first delay model and 2 death cases in the third delay model, but there was no maternal death in the second delay model.

Conclusion: Maternal death is an significant public health issue which develops due to the generally preventable causes and maintains its importance. The factors contributing to death should be paid attention in order to decrease maternal death rates.
\end{abstract}

Keywords: Maternal death rate, direct causes, indirect causes.
Özet: Elazığ ilinde 2015-2020 yılları arasında meydana gelen anne ölümlerinin değerlendirilmesi

Amaç: İlimizde meydana gelen anne ölümleri ile bunları etkileyen faktörlerin belirlenmesi.

Yöntem: Ocak 2015 ile Haziran 2020 tarihleri arasında ilimizde gerçekleşen maternal ölümler retrospektif olarak incelendi. İnceleme İl Sağlık Müdürlüğ̈̈ 'Anne Ölüm Kayıt Formları' verilerine bakılarak yapıldı. Ölüm sebebiyle ilgili ilave veri gereksinimi olan durumlarda olgunun yakınları, bağı bulunduğu aile hekimi, Adli Tıp Kurumu veya yerel yöneticiler ile temas kuruldu. Olguların yaş, gravida, parite, abortus, doğum şekli, doğumun gerçekleştiği gebelik haftası, ölümün gerçekleștiği dönem ve doğrudan, dolaylı ve tesadüfi nedenlerle gerçekleşen anne ölümleri kaydedildi. Altı buçuk yıldaki toplam canlı doğumlar ve anne ölümleri temel alınarak maternal mortalite oranı, 100.000 canlı doğumdaki anne ölüm sayısı olarak belirlendi. Verilerin istatistiksel değerlendirmesinde tanımlayıcı istatistik kullanıld.

Bulgular: Elazı '̆'da 2015-2020 yılları arasında toplam 46.618 canlı doğum gerçekleşti. Doğrudan ve dolaylı nedenlere bağı anne ölümlerinin sayısı 7 olup, anne ölüm oranı yüz binde 15.01 olarak tespit edildi. Anne ölümlerinin doğrudan nedenleri arasında, gebelikte hipertansif hastalklar $(\mathrm{n}=3, \% 42.8)$, pulmoner emboli $(\mathrm{n}=1, \% 14.3)$ ve serebral tromboz $(\mathrm{n}=1, \% 14.3)$ olduğu belirlendi. Dolaylı anne ölüm nedeni ise kalp hastalıkları (n=2, \%28.6) idi. Üç Gecikme Modeli'ne göre sınıflandırıldığında ilk gecikme modelinde 3 ölüm, üçüncü gecikme modelinde 2 ölüm gerçekleşirken, ikinci gecikme modeline bağlı anne ölümü izlenmediği tespit edildi.

Sonuç: Anne ölümleri çoğu önlenebilir nedenlere bağlı gelișen ve önemini koruyan önemli bir halk sağlı̆̆ problemidir. Anne ölümlerinin azaltılması için ölümlere katkıda bulunan faktörlerin farkında olunmalıdır.

Anahtar sözcükler: Anne ölüm oranı, doğrudan nedenler, dolaylı nedenler.

Correspondence: Salih Burçin Kavak, MD. Department of Obstetrics and Gynecology, Faculty of Medicine, Fırat University, Elazı̆̆, Turkey. e-mail: burcinkavak1@gmail.com / Received: September 1, 2020 ; Accepted: October 2, 2020

Please cite this article as: Batmaz İ, Kavak SB, Çelik Kavak E, Gül E, Şanlı C, Bulu G, Keser HB. The assessment of maternal deaths between 2015 and 2020 in Elazı̆̆, Turkey. Perinatal Journal 2020;28(3):183-189. doi:10.2399/prn.20.0283008 


\section{Introduction}

In 2017, approximately 295,000 women died during pregnancy or delivery or after delivery in the worldwide. Ninety-four percent of these deaths occurred in regions with low socio-economic levels, and $98 \%$ of all maternal deaths are associated with preventable causes. ${ }^{[1,2]}$ The complications during pregnancy and delivery are the most important morbidity and mortality causes in fertile women in the developing countries. Maternal death rate (MDR) represents the obstetric risk, and it is also an indicator of United Nations Millennium Development Goals. MDR is the number of annual woman deaths per 100,000 live births within 42 days after the termination of pregnancy or for any reason aggravated by or associated with pregnancy and its management (except accidents or incidental causes). ${ }^{[1,3-6]}$

Pregnancy-related death is defined as the death of a woman during pregnancy or within 42 days after the termination of pregnancy regardless of death cause, and it includes incidental causes as well as direct and indirect maternal death causes. ${ }^{[3,4,6]}$

Maternal death is still a serious and common public health issue in developing countries. ${ }^{[7]}$ MDR is a good indicator for the quality of healthcare. ${ }^{[8,9]}$ It is important to determine the causes of maternal deaths and delays contributing to deaths in planning and offering healthcare services.

The objective of our study is to determine the causes of maternal deaths and delay models in our region.

\section{Methods}

All maternal death cases occurred between January 2015 and June 2020 in all healthcare institutions affiliated with
Elazığ Provincial Directorate of Health were reviewed retrospectively in our study. The approval of local ethics committee was obtained for the study from the Elazıg Directorate of Public Health Services on 29.06.2020 (Ethics Committee Approval No.: E.483). The review was conducted by checking the data of "Maternal Death Registry Forms". In cases where additional data related with the cause of death were required, the relatives of the cases, associated family practitioner, The Council of Forensic Medicine or local authorities were contacted. The data of the cases including age, gravida, parity, abortion, delivery type, week of gestation during delivery, period of death and maternal deaths due to direct, indirect and incidental causes were recorded. Based on total live births and maternal deaths within 6.5 years, maternal mortality rate was found as the maternal death number per 100,000 live births.

SPSS 22.0 statistics software (SPSS Inc., Chicago, IL, USA) and the descriptive statistics were used to evaluate the data.

\section{Results}

There were 9 maternal deaths in total between January 2015 and June 2020 in Elazı $\breve{g}$. Total live birth number is 46.618 within these 6.5 years. When direct and indirect maternal death causes were evaluated, the MDR was found 15.01/100,000 (Table 1). Incidental causes were not included in this rate.

When the cases were reviewed, it was found that mean maternal age was $33.6 \pm 3.15$ (range: $28.5-38$ ) years, week of gestation during delivery was $34.2 \pm 5.26$ (range: $26-40$ ) weeks, gravida was $3.3 \pm 1.38$ (range: $2-5$ ), living children were $2.6 \pm 1.27$ (range 1-4), parity was $2.4 \pm 1.61$ (range:

Table 1. The distribution of maternal death causes between 2015 and 2020 in Elazığ.

\begin{tabular}{lccccccc} 
Year & $\begin{array}{c}\text { Number of } \\
\text { live births } \\
\text { (number) }\end{array}$ & $\begin{array}{c}\text { Death during } \\
\text { pregnancy } \\
\text { (number) }\end{array}$ & $\begin{array}{c}\text { Death after } \\
\text { delivery } \\
\text { (number) }\end{array}$ & $\begin{array}{c}\text { Direct and indirect } \\
\text { death causes } \\
\text { (number) }\end{array}$ & $\begin{array}{c}\text { Incidental } \\
\text { death cause } \\
\text { (number) }\end{array}$ & $\begin{array}{c}\text { Total } \\
\text { deaths } \\
\text { (number) }\end{array}$ & $\begin{array}{c}\text { Maternal } \\
\text { death rate } \\
(/ 100,000)\end{array}$ \\
\hline 2015 & 8916 & - & - & - & - & - \\
\hline 2016 & 8762 & - & - & - & - & - \\
\hline 2017 & 8719 & - & 3 & 2 & 1 & 3 & 22.9 \\
\hline 2018 & 8332 & - & 2 & 2 & 0 & 2 & 24 \\
\hline 2019 & 7955 & - & 2 & 2 & 0 & 2 & 25.1 \\
\hline 2020 (First 6 months) & 3934 & 1 & 1 & 1 & 1 & 2 & 25.2 \\
\hline Total & 46,618 & 1 & 8 & 7 & 2 & 9 & 15.01 \\
\hline
\end{tabular}


$1-5$ ), abortion was $0.6 \pm 0.53$ (range: $0-1$ ) and the time of death after delivery was $16.1 \pm 14.02$ (range: $1-36$ ) days (Table 2). Four cases delivered by cesarean section, 2 cases delivered vaginally and one case died after abortion.

Seven $(77.8 \%)$ of 9 maternal deaths were due to direct or indirect causes, and 2 (22.2\%) of them were due to incidental causes (Table 1). One case died at the second trimester of pregnancy due to earthquake, one case died at a traffic accident after delivery, 6 cases died after delivery and one case died after abortion. All mothers died due to direct or indirect causes delivered at hospital, and the case who underwent abortion was under treatment at hospital.

In our study, hypertensive diseases seen during pregnancy $(n=3,42.8 \%)$ were the most common direct causes of maternal death, which was followed by pulmonary embolism $(n=1,14.3 \%)$ and cerebral thrombosis $(n=1$, $14.3 \%$ ). Cardiac diseases were found as the indirect death cause $(n=2,28.6 \%)$. The incidental causes of maternal deaths among pregnancy-related deaths are traffic accidents $(n=1,11.1 \%)$, and earthquake $(n=1,11.1 \%)$; however, these data were not included in maternal death rates (Table 3).

The percentages of direct, indirect and incidental causes for maternal deaths are shown in Fig. 1.

"Three Delays Model" was recommended by the World Health Organization (WHO) ${ }^{[10]}$ When they were categorized according to the recommendation of WHO, there were 3 death cases in the first delay model and 2 death cases in the third delay model. There was no maternal death in the second delay model. No delay was
Table 2. The obstetric characteristics of mothers died between 2015 and 2020 in Elazığ

\begin{tabular}{lccc} 
Characteristics & Min. & Max. & Mean \pm SD \\
\hline Age (year) & 28.5 & 38 & $33.6 \pm 3.15$ \\
\hline Week of gestation during delivery (week) & 26 & 40 & $34.2 \pm 5.26$ \\
\hline Gravida (number) & 2 & 5 & $3.3 \pm 1.38$ \\
\hline Living child (number) & 1 & 4 & $2.6 \pm 1.27$ \\
\hline Parity (number) & 1 & 5 & $2.4 \pm 1.61$ \\
\hline Abortion (number) & 0 & 1 & $0.6 \pm 0.53$ \\
\hline Time of death (day) & 1.00 & 36.00 & $16.1 \pm 14.02$ \\
\hline
\end{tabular}

observed in 4 cases. Also, there was no delay in the incidental deaths $(\mathrm{n}=2)$.

\section{Discussion}

Maternal death is a significant indicator of woman health in both developed and developing countries. ${ }^{[1]}$ In the entire world, about $86 \%$ of maternal deaths in 2017 occurred in Sub-Saharan Africa $(196,000)$ and South Africa $(58,000)$. While MDR was 542 per 100,000 live births in Sub-Saharan Africa in 2017, this rate was between 6 and 11 in the countries with high income levels. Although a reduction of $75 \%$ in the rate was aimed from 1990 to 2015 by United Nations Millennium Development Goals, the goal could not be achieved with only a reduction of $45 \%$ until today. ${ }^{[12]}$ If the current progress does not change despite all the measures taken and the efforts made, the world will stay about 1 million lives behind this goal by the year $2030 .^{[1]}$

Table 3. The distribution of the causes of all maternal deaths between 2015 and 2020 in Elazığ.

\begin{tabular}{|c|c|c|c|}
\hline Cause of death & $\mathbf{n}$ & $\begin{array}{l}\text { Pregnancy-related deaths } \\
\text { (\%) }\end{array}$ & $\begin{array}{c}\text { Maternal deaths } \\
(\%)\end{array}$ \\
\hline \multicolumn{4}{|l|}{ Direct causes of death } \\
\hline Hypertensive diseases during pregnancy & 3 & 33.4 & 42.8 \\
\hline Pulmonary embolism & 1 & 11.1 & 14.3 \\
\hline Cerebral thrombosis & 1 & 11.1 & 14.3 \\
\hline Obstetric hemorrhage & - & - & - \\
\hline \multicolumn{4}{|l|}{ Indirect causes of death } \\
\hline Cardiac disease & 2 & 22.2 & 28.6 \\
\hline \multicolumn{4}{|l|}{ Incidental causes of death } \\
\hline Traffic accident & 1 & 11.1 & 0 \\
\hline Earthquake & 1 & 11.1 & 0 \\
\hline Total & 9 & 100 & 100 \\
\hline
\end{tabular}




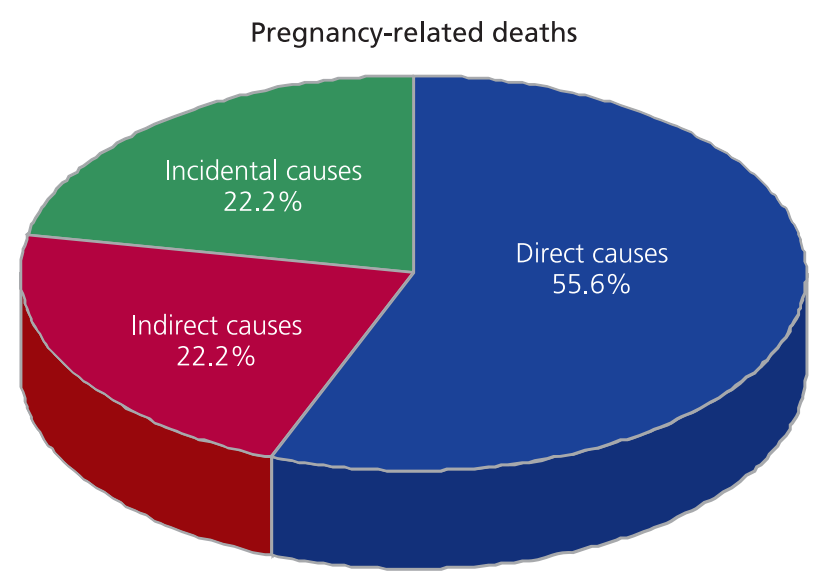

Direct causes
The causes of pregnancy-related deaths

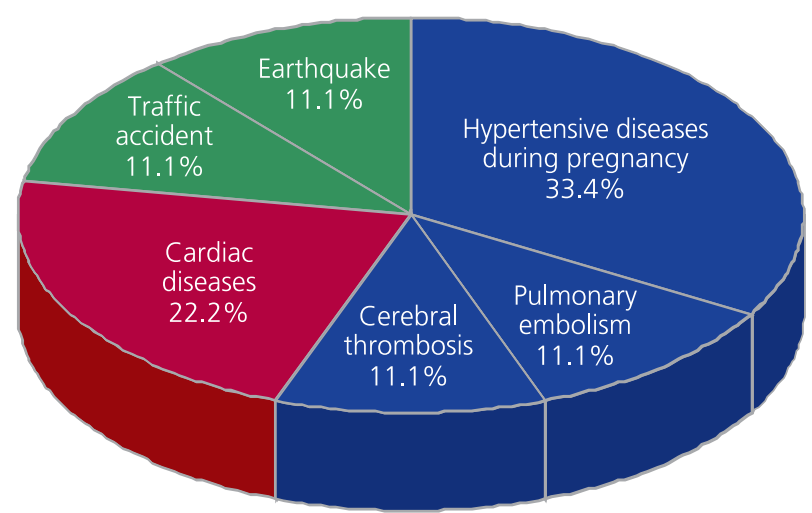

Incidental causes

Fig. 1. The causes of pregnancy-related deaths between 2015 and 2020 in Elazığ.

According to the Maternal Death Data System used for the Program of Tracking Maternal Deaths in Turkey, MDR in Turkey was reported to decrease to $13.6 / 100,000$ in 2018 from 16.4/100,000 in 2010. In our study, we found MDR 15.01/100,000 in Elazı̆g, which was above the average in Turkey. The data of 2019 and 2020 had not been published by Turkish Statistical Institute yet during the study period. ${ }^{[1,1,1]}$

The maternal deaths are categorized according to the causes and delay models recommended by $\mathrm{WHO} .^{[10]}$ Accordingly, the direct maternal deaths are those caused by the obstetrics complications or any treatments during pregnancy, delivery or postpartum period which is the first 42 days after delivery, and the indirect maternal deaths are those caused by non-obstetric reasons due to a disease or diseases developing during pregnancy or already existing before delivery but exacerbated by the physiological effects of pregnancy. The incidental deaths are those occurring during pregnancy, delivery or within 42 days after delivery and not related with any direct or indirect obstetric reasons (not related with any effects of pregnancy) (i.e. accidents, suicide, poisoning etc.).

When evaluating the maternal deaths, individual, social and healthcare service factors that contribute deaths should also be taken into consideration as well as medical reasons. Three Delays Model developed for this purpose categorizes the delays causing maternal deaths in three groups as below:
Delay Model 1: The delay in decision to seek healthcare service for any reason

Delay Model 2: The delay in reaching a convenient medical facility for any reason

Delay Model 3: The delay in receiving adequate medical care in the healthcare institution for any reason.

When we evaluated the maternal deaths occurred in our city according to the Three Delays Model, we found that there were delays in $71.4 \%$ of the maternal deaths. Of these cases, $42.9 \%$ belong to Delay Model 1 and $28.5 \%$ belong to Delay Model 3. There was no case in Delay Model 2 in the last 7 years in region (Table 4). Three mothers who died were referred to our hospital from the healthcare institutions in the districts via 112 emergency medical service. The results show that the mothers reach health facilities in a fast, healthy and safe way by ambulances particularly in rural areas by means of the services offered by 112 Emergency Medical Services.

A large-scale study involving the years 2003 and 2009 reported that about $73 \%$ of the maternal deaths in the world occurred due to direct causes and $27.5 \%$ by indirect causes. Hemorrhage is the most common direct reason for maternal deaths in the world with a rate of $27.1 \%$. More than one-third of the hemorrhage-related deaths occurred at the end of delivery. Hypertension is the second most common direct cause for maternal deaths with a rate of $14 \%$. The other common direct causes of maternal deaths are sepsis (10.7\%), abortion (7.9\%), and embolism and other direct causes $(12.8 \%){ }^{[5]}$ 
Table 4. The delay models of maternal deaths between 2015 and 2020 in Elazığ.

\begin{tabular}{|lccccc} 
Year & $\begin{array}{c}\text { Maternal death } \\
\text { (number) }\end{array}$ & $\begin{array}{c}\text { 1st Delay Model } \\
\text { (number) }\end{array}$ & $\begin{array}{c}\text { 2nd Delay Model } \\
\text { (number) }\end{array}$ & $\begin{array}{c}\text { 3rd Delay Model } \\
\text { (number) }\end{array}$ & $\begin{array}{c}\text { No Delay Model } \\
\text { (number) }\end{array}$ \\
\hline 2015 & - & - & - & - & - \\
\hline 2016 & - & - & - & - & - \\
\hline 2017 & 3 & - & - & - & 2 \\
\hline 2018 & 2 & 2 & - & 1 & - \\
\hline 2019 & 2 & - & - & - & 1 \\
\hline 2020 & 2 & 1 & - & 2 & 4 \\
\hline Total & 9 & 3 & - & 2 \\
\hline
\end{tabular}

The most common indirect cause of maternal deaths is cardiac diseases. ${ }^{[4,8]}$

According to the report of National Maternal Death Study, $58.4 \%$ of the pregnancy-related maternal deaths occurred in Turkey in 2005 were due to direct causes, $15.8 \%$ due to indirect causes, $2.4 \%$ due to pregnancyrelated but unknown causes, and $23.2 \%$ due to incidental causes. While MDR due to direct causes was $78.8 \%$, it was $21.2 \%$ for indirect causes. It was reported that the direct causes of maternal deaths in Turkey were antepartum, intrapartum and postpartum hemorrhage with a rate of $24.9 \%$, hypertensive diseases during pregnancy with a rate of $18.4 \%$, infection with a rate of $4.6 \%$, and other causes with a rate of $15.7 \%$ in total such as embolism, surgical complications and uterine rupture. It was reported that circulatory system diseases were the most common indirect cause of maternal deaths with a rate of $47.8 \%$, and the traffic accidents were the most common incidental cause of maternal deaths with a rate of $47.1 \% .^{[4]}$

In our study, we found that $77.8 \%$ of maternal deaths occurred due to direct $(\mathrm{n}=5)$ or indirect $(\mathrm{n}=2)$ causes, and $22.2 \%(n=2)$ of them occurred due to incidental causes. The most common direct cause of maternal deaths was hypertensive diseases during pregnancy $(n=3,42.8 \%)$ followed by pulmonary embolism $(n=1,14.3 \%)$ and cerebral thrombosis $(\mathrm{n}=1,14.3 \%)$. The indirect cause of maternal deaths was cardiac diseases $(\mathrm{n}=1,28.6 \%)$. MDR which has been associated with pregnancy directly and indirectly in the last 6.5 years $(\mathrm{n}=1,15.01 \%)$ was found lower $(\mathrm{n}=12,18.6 \%)$ than the rate found by Kavak et al. in their study conducted in the same region. ${ }^{[15]}$ Also, the maternal death rate associated with obstetric hemorrhage was $25 \%$ in that study while we did not observe any maternal death associated with hemorrhage at the end of delivery in our study. The incidental causes of maternal deaths in our study were traffic accident and earthquake. Pregnancy-related hypertension complications which we can refer to as "silent enemy" has been the primary cause of maternal death in our region ( $41.7 \%$ vs. $42.8 \%$ in our study).

The most common cause of maternal deaths in the world are obstetric hemorrhage, and they usually develop within the first two days after delivery. ${ }^{[2,4,5,16,17]}$ There was no maternal death related with obstetric hemorrhage in our study. This shows that the experience of healthcare professionals in our region has increased, the healthcare institutions are in adequate number and equipped, and there is few or no delay in reaching healthcare facilities.

Hypertensive diseases during pregnancy are the leading cause of maternal death in developed countries. On the other hand, hypertensive diseases during pregnancy are the most common cause of maternal death after hemorrhage. ${ }^{[5,16]}$ Kavak et al. ${ }^{[15]}$ reported in their study conducted on maternal deaths in Elazı ğ between 2007 and 2013 that the hypertensive diseases during pregnancy $(n=5,41.7 \%)$ were the most common direct cause of maternal deaths. Similar to the study of Kavak et al., ${ }^{[15]}$ we found that the hypertensive diseases during pregnancy $(n=3,4.8 \%)$ were the most common direct cause of maternal deaths, and its contribution to MDR has not changed despite the seven years that has passed. Although there are screening methods for preeclampsia prediction, the power of screening is not still sufficient. Hypertensive diseases during pregnancy should be explained well to healthcare professionals by onthe-job trainings and pregnant women by educational 
sessions, the awareness of pregnant women should be raised and early diagnosis should be ensured. Appropriate pregnant women should be informed by determining delivery time in advance in order to prevent potential delays, and healthcare professionals should be informed by on-the-job trainings about hypertensive diseases during pregnancy, obstetric hypertensive emergencies and treatment protocols and $\mathrm{MgSO}_{4}$ treatment.

The studies conducted showed that advanced maternal age ( $>35$ years old), increase in the number of parity or abortion and socio-economic level are associated with maternal mortality and morbidity. ${ }^{[18,19]}$ The women in underdeveloped countries have more pregnancies than the women in developed countries, ${ }^{[20]}$ and therefore, they have higher life-long death risk due to pregnancy. ${ }^{[1]}$ The life-long maternal death risk of a woman is the probability of death of a 15-year-old woman due to motherhood. This rate is $1 / 5400$ in the countries with high income levels while it is $1 / 45$ in the countries with low income levels. ${ }^{[1,4]}$

In our study, $14.3 \%$ of the cases $(n=1)$ were 35 years old and above and $14.3 \%$ of them were grand multiparous (pregnancy for more than 5 times, $n=1$ ). Thirtyfive-year-old case died due to the middle cerebral artery thrombosis. The grand multiparous case died due to the eclampsia-related intracranial hemorrhage. The death of one case after abortion was not due to abortion complications but acute coronary syndrome, which is one of the indirect causes of maternal death. We observed that advanced maternal age and high parity may have an effect on maternal death.

The rates of pregnancy and labor complications in teenage girls between 10 and 19 years old are higher than the women between 20 and 24 years old, and the maternal mortality risk is the highest in the teenage girls younger than 15 years old. ${ }^{[2,22]}$ In our study, we found that there was no maternal death among women younger than 20 years old between 2015 and 2020 .

Most of maternal deaths occur between third trimester and the first week after the termination of pregnancy, and its incidence is very high particularly during the first two days after delivery. ${ }^{[4,23]}$ In our study, the mean period for maternal deaths is $16 \pm 14.1$ (range: 1-36) days after delivery, and one mother died at postpartum 6th hour.

\section{Conclusion}

Maternal deaths due to preventable causes have been observed at a high rate. The delays in the management of patients still have a high frequency. A preventive plan is needed in our region for the hypertensive diseases seen during pregnancy. Determining the causes of and delays in maternal deaths would provide great contributions to the planning of healthcare services in future.

Conflicts of Interest: No conflicts declared.

\section{References}

1. Trends in maternal mortality: 2000 to 2017. Estimates by WHO, UNICEF, UNFPA, the World Bank Group and the United Nations Population Division. [Internet]. Geneva: World Health Organization; 2019. [updated 2019 Sept; cited 2020 Feb 05]. Available from: https://data.unicef.org/ resources/trends-maternal-mortality-2000-2017/

2. Ronsmans C, Graham WJ; Lancet Maternal Survival Series Steering Group. Maternal mortality: who, when, where, and why. Lancet 2006;368:1189-2000. [PubMed] [CrossRef]

3. WHO. Maternal mortality ratio (per 100,000 live births). [Internet]. Geneva: World Health Organization; 2019. [cited 2020 Jan 14]. Available from: https://www.who.int/healthinfo/statistics/indmaternalmortality/en/

4. Hacettepe University Institute of Population Studies. Reproductive Health Programme. Turkey National Maternal Mortality Study, 2005. Main report. [nternet]. Ankara: Ministry of Health, General Directorate of Mother and Child Health and Family Planning and Delegation of European Commission to Turkey; 2006. [cited 2020 Jan 23]. Available from: http://www. hips.hacettepe.edu.tr/eng/maternal_mortality/NNMS2005_main_report.pdf

5. Say L, Chou D, Gemmill A, Tuncalp O, Moller AB, Daniels JD, et al. Global causes of maternal death: a WHO systematic analysis. Lancet Global Health 2014;2:e323-e33. [PubMed] [CrossRef]

6. Maternal mortality. Maternal mortality declined by 38 per cent between 2000 and 2017. [Internet]. New York, NY: UNICEF; 2019. [updated 2019 Sept; cited 2020 Apr 11]. Available from: https://data.unicef.org/topic/maternal-health/ maternal-mortality/

7. Brown G, Allen L, Torkelson A. Direct patient interventions that can reduce maternal mortality in developing countries:a systematic review. Fam Med 2013;45:550-7. [PubMed]

8. Üstün YE, Celen S, Ozcan A, Sanisoglu S, Karaahmetoglu S, Gül R, et al. Maternal mortality from cardiac disease in Turkey: a population-based study. J Matern Fetal Neonatal Med 2012;25:2451-3. [PubMed] [CrossRef]

9. Schutte JM, Steegers EAP, Schuitemaker NWE, Santema JG, de Boer K, Pel M, et al.; Netherlands Maternal Mortality Committee. Rise in maternal mortality in the Netherlands. BJOG. 2010;117:399-406. [PubMed] [CrossRef] 
10. WHO. Beyond the numbers: reviewing maternal deaths and complications to make pregnancy safer. [Internet]. Geneva: World Health Organization; 2004. [cited 2020 Feb 19]. Available from: https://apps.who.int/iris/handle/10665/42984

11. Høj L, da Silva D, Hedegaard K, Sandstrom A, Aaby P. Maternal mortality: only 42 days? Br J Obstet Gynaecol 2003; 110:995-1000. [PubMed] [CrossRef]

12. Trends in maternal mortality: 1990 to 2013. Estimates by WHO, UNICEF, UNFPA, the World Bank Group and the United Nations Population Division. [Internet]. Geneva: World Health Organization; 2014. [cited 2020 Feb 26]. Available from: https://www.who.int/reproductivehealth/ publications/monitoring/maternal-mortality-2013/en/

13. TUIK. Dünya Nüfus Günü, 2020. TUIKK Haber Bülteni, Sayı: 33707. [Internet]. Ankara: TÜİK. [cited 2020 Jul 16]. Available from: http://www.tuik.gov.tr/PreHaberBultenleri.do?id= 33707

14. Türkiye Cumhuriyeti Sağlık Bakanlığı. Sağlık İstatistikleri

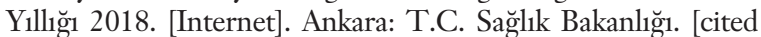
2020 Mar 25]. Available from: https://www.saglik.gov.tr/ TR,62400/saglik-istatistikleri-yilligi-2018-yayinlanmistir.html

15. Kavak SB, Kavak EC, Demirel I, Turkoglu A, Akkus IH, Ilhan $\mathrm{R}$, et al. Evaluation of maternal mortality cases in the province of Elazig, Turkey, 2007-2013: a retrospective study. Glob J Health Sci 2015;7:188-93. [PubMed] [CrossRef]

16. Khan KS, Wojdyla D, Say L, Gulmezoglu AM, Van Look PF. WHO systematic review of causes of maternal deaths: a systematic review. Lancet 2006;367:1066-74. [PubMed] [CrossRef]
17. Shayan NA, Özcebe H. Maternal mortality: a comparison of Afghanistan and its neighboring countries. [Article in Turkish] Türkiye Halk Sağlığı Dergisi 2017;15:222-32. [CrossRef]

18. Atrash HK, Koonin LM, Lawson HW, Faranks AL, Smith JC. Maternal mortality in the United States, 1979-1986. Obstet Gynecol 1990;76:1055-90. [PubMed]

19. Högberg U, Innala E, Sandström A. Maternal mortality in Sweden, 1980-1988. Obstet Gynecol 1994;84(2):240-4. [PubMed]

20. United Nations, Department of Economic and Social Affairs, Population Division. World population prospects 2019: Highlights (ST/ESA/SER.A/423). [Internet]. New York, NY: UN; 2019. [cited 2020 Feb 04]. Available from: https:// population.un.org/wpp/Publications/Files/WPP2019_High lights.pdf

21. Ganchimeg T, Ota E, Morisaki N, Laopaiboon M, Lumbiganon P, Zhang J, et al.; WHO Multicountry Survey on Maternal Newborn Health Research Network. Pregnancy and childbirth outcomes among adolescent mothers: a World Health Organization multicountry study. BJOG 2014;121 Suppl 1:40-8. [PubMed] [CrossRef]

22. Althabe F, Moore JL, Gibbons L, Berrueta M, Goudar SS, Chomba E, et al. Adverse maternal and perinatal outcomes in adolescent pregnancies: The Global Network's Maternal Newborn Health Registry study. Reprod Health 2015; 12(Suppl 2):S8. [PubMed] [CrossRef]

23. Li XF, Fortney JA, Kotelchuck M, Glover LH. The postpartum period: the key to maternal mortality. Int J Gynaecol Obstet 1996;54:1-10. [PubMed] [CrossRef] 